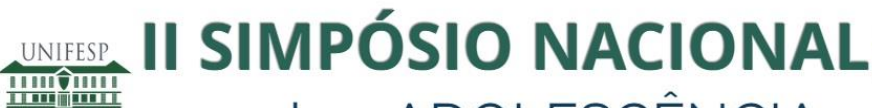 sobre ADOLESCÊNCIA: Vulnerabilidades, Protagonismos e Desafios
}

\section{Intervenção Psicossocial (uso de cenas) no processo de Revelação Secundária em jovens órfãos por aids soronegativos}

\author{
Yone Fonseca \\ Vera Paiva \\ Ivan França Junior \\ Barros Claudia
}

\section{Como citar:}

FONSECA, Yone et al. Intervenção Psicossocial (uso de cenas) no processo de Revelação Secundária em jovens órfãos por aids soronegativos. In: SIMPÓSIO NACIONAL SOBRE ADOLESCÊNCIA: VULNERABILIDADE, PROTAGONISMOS E DESAFIOS, 2, 2016, São Paulo. Anais...[S. I.]: 2016. p. 35.

DOI: http://dx.doi.org/10.22388/2525-5894.2016.013

Introdução: a metodologia das cenas permite conhecer e compreender os cenários culturais, e os scripts das pessoas envolvidas no processo de revelação, seguindo a perspectiva construcionista e dos Direitos Humanos aplicados à saúde. O uso das cenas como recurso de intervenção psicossocial é uma estratégia eficaz para atuação no processo de revelação. A maior parte dos estudos sobre a revelação da condição de pessoas vivendo com aids descrevem e analisam o modo como estas pessoas contam o seu diagnóstico para parceiros sexuais e cônjuges, filhos e profissionais de saúde. Quando as crianças e adolescentes estão envolvidos, os pais e/ou cuidadores enfrentam muitas dificuldades e tendem a postergar a revelação do diagnóstico de seus filhos soropositivos ou a revelar que ele/ela mesmo/a é portador(a) do HIV. Um aspecto que tem sido pouco explorado é como a revelação secundária do diagnóstico e causa morte dos pais por aids afeta a vida dos chamados "órfãos da aids".

Objetivo: descrever como uso das cenas como intervenção psicossocial pode contribuir para a compreensão de como ocorre a revelação (ou não) da causa morte dos pais por jovens, possibilitando também a análise de sua experiência de orfandade por aids.

Metodologia: estudo de desenho qualitativo analisou entrevistas realizadas com treze jovens de ambos os sexos. As entrevistas abordaram a estrutura familiar e doméstica, as lembranças e a experiência da perda dos pais e de orfandade, bem como as cenas de revelação da causa morte dos pais - especialmente como lidavam, como comunicavam, ou não, sobre a causa morte por aids para outras pessoas.

Resultados: nenhum dos entrevistados se identificou centralmente como órfão - noção que é associada ao abandono. Observou-se que como em outros países, pais e/ou cuidadores tiveram dificuldades com a revelação do diagnóstico a seus filhos e que metade dos jovens não revelou a causa de morte dos pais por medo do estigma. 
Considerações Finais: a não revelação gerou o gerenciamento de um segredo de família e o desafio de dar conta de múltiplas revelações - do comportamento dos pais e de outros segredos que o medo da discriminação produz. Derivamos deste estudo propostas de intervenção psicossocial (a partir da revisão de algumas diretrizes já existentes para o atendimento de crianças e jovens que convivem com HIV), e de ações para atenção a esses jovens e auxílio no processo de revelação, pautadas pela abordagem psicossocial no quadro da vulnerabilidade e direitos humanos - perspectiva teórica utilizada para fundamentar o estudo.

Palavras-chave: Revelação. Orfandade. AIDS. Cenas. Intervenção psicossocial. 